\title{
Making Short Politics Placements Work
}

(Word count: 3834 including title, abstract and bibliography)

\begin{abstract}
Short placements can provide an important and meaningful experience of politics in action for students who are unable to benefit from the generally lengthy placements currently on offer. This article is based on the findings of the three-year HEFCE-funded project The Scholarship of Engagement for Politics and explores the potential of short, local, research-based placements, embedded in modules and supported by online journaling, to enrich students' understanding of politics and enhance their employability.
\end{abstract}

\section{Introduction}

Placement learning is potentially a very powerful pedagogical tool. It can provide students with real world experiences which they can use to illustrate and compare against the concepts and theories they learn about in the classroom and from textbooks, thereby enriching their understanding of the subject matter of their courses. Experience of the world beyond the campus also directly addresses the issue of employability, which has become a pressing matter for employers and the government, along with a concern - one of long standing in the United States, but increasingly in the UK - with educating active and engaged citizens (Annette, 2005; Barber and Battistoni, 1993; Colby et al, 2003, 2007). Finally, the opportunity to go on a placement as part of a degree course is attractive to many student applicants and can thus boost undergraduate recruitment. Therefore it is not accidental that 
placement learning has become such a popular means of engaging students with the content of their courses across the country.

However, the benefits of placement learning are often muted by a number of factors. With an increasing proportion of undergraduates finding it necessary to take part-time jobs, and for students with family commitments, the opportunities to undertake extended placements will be severely limited. A colleague who arranges placements for Graphic Design students told us that most of her students would prefer to undertake simulated projects at the university rather than incur the additional costs of time and travel associated with a placement. It is also frequently the case that placement experiences are inadequately tied to the academic content of courses. In most cases students are responsible for finding and negotiating their placements without sufficient guidance. This is especially the case with sandwich degrees, where placements are often tangentially related at best to the subject matter of student courses.

Politics placements have a long and distinguished heritage. For over twenty years Lord Norton of Louth has arranged year-long placements with MPs as a formal part of the British Politics and Legislative Studies course at the University of Hull (Norton, 2004, 2008), with similar programmes taking root at the universities of Leeds and Salford; and since the late 1980s the University of Huddersfield has made a level-two work-placement module a mandatory element of its BA Politics programme. Our 2006-07 survey of the use of placements in named Politics and International Relations departments across the British Isles discovered that 31 of the 96 departments surveyed makes some use of placement learning in one form or another. However, many of the above noted limitations may well be at work, with almost half of these 31 departments employing year-long placements, and nearly three quarters requiring placements of ten weeks or longer. Therefore, for all of its potential, it appears that placement learning opportunities for Politics students are frequently restricted in a number of respects: they are lengthy, are often with traditional national 
political actors - usually MPs - in London, and when they are integrated into degree courses, they are capped in terms of numbers and allocated on a competitive basis. After all, there are only 646 MPs.

\section{The Scholarship of Engagement for Politics}

The Scholarship of Engagement for Politics was a three-year research project involving the politics departments of Coventry University, Oxford Brookes University and the Universityof Warwick, with the aim of developing templates of placement learning which could be embedded in the politics curriculum. It al so sought to evaluate the impact of placements on student learning and the effectiveness of assessment techniques. The project was informed by developments in the pedagogy of politics on both side of the Atlantic concerned with the use of experiential learning for educating citizens (e.g., Annette, 2003; Battistoni and Hudson, 1997), although our focus was primarily on the enrichment of students' knowledge of politics rather than the nurturing of active citizens. In addition, we werekeen to avoid some of the problems with making connections between students' experiences and course content (e.g., Zivi, 1997, pp. 53-55). Indeed, only $1 \%$ of servicelearning programmes in the US involve explicitly political activity (Colby et al, 2007, p. 5). In terms of the effect of placements on student learning, the extensive US experience of service-learning indicates that such activity can yield significant if not necessarily large benefits (Eyler and Giles, 1999, p. xvii; Marcus, Howard and King, 1993).

We sent 36 students on short placements to a pool of 18 place ment providers and evaluated their experiences through their written work (essays, learning diaries, reports), the online web logs (blogs) which they kept while on placement, structured post-placement de-briefings with each student individually, and a questionnaire completed by every student six months after the completion of 
their placements. The questionnaire introduced a quantitative dimension into our generally qualitative evaluation methodology, but it also allowed us to capture any delayed effects as well as to measure the impact of placements on the students' subsequent studies.

Besides devising means of embedding placements into the undergraduate curriculum, the project also made important contributions to the practice of placement learning in terms of the development of a research-based approach to placements (with, as it turned out, important implications for employability), the use of blogs for the recording of student reflections, and exploring the impact of assessment regimes on the nature of placements. The remainder of this article will consider these contributions to the practice of placement learning in turn.

\section{Going short, local and embedded}

To make the benefits of real-world experience available to as many students as possible, as well as to liberate placement learning and strengthen it as a pedagogical tool, we developed a new approach to placements in terms of their duration, location and relation to course content. Our politics placements were very short, predominantly local and fully integrated into the curriculum.

We devised placements ranging in length from five to 16 days, thus making placement learning a possibility for students with part-time jobs and dependent families, as well as those unwilling to incur the costs of adding a fourth year to their degree programmes. This also made it feasible to run placements during the academicyear, creating affordances for the interplay between experiential and class-based learning. The placements were scheduled in a variety of ways, from a on e-week block during reading week to two days a week over three to eight weeks, so as to interrupt students' studies as little as possible. Although current practice and studies tend to suggest the importance of 
extended placement activities (e.g., Hepburn, Niemi and Chapman, 2000), we found that a week can be a long time in the teaching and learning of politics. Although most of the students suggested in their post-placement debriefings that longer placements would have further enhanced their understanding, nonetheless the impacts were still significant. In response to the follow-up questionnaire administered six months after their placements, $96 \%$ agreed that they had learned a lot from their placements and $75 \%$ responded that the experience had exceeded their expectations. In terms of enriching students' understanding of politics, 78\% agreed that their experience had improved their grasp of the subject and $72 \%$ said they had drawn on their experiences in their subsequent course assignments.

While a small number of our students were sent on placements in Brussels or were invited to certain events in London by their placement providers, most of the placements were local, again to minimize the financial and travelling costs and to interfere with students' studies as little as possible, but also to take advantage of the learning opportunities on our doorsteps. We placed students with local and regional government bodies, the constituency offices of MPs and MEPs, and local NGOs and othervoluntary groups. Many students were able to make a direct connection between their studies and their placement activities (for example, a student studying a module on the European Union who we placed in an MEP's constituency office put her knowledge into practice as well as gaining a real insight into and renewed respect for an MEP's work); but even when academic content and placement experience were not so intimately acquainted (for example, the students on British politics modules focused on Westminster who were placed with city councils), most students said that their placement experiences had complemented their understanding of politics by presenting them with a new dimension or something that they would not otherwise have studied.

Finally, the placements were embedded in the students' degree programmes, not just in the sense that they ran alongside their studies, but also as they were fully integrated into level-two modules. 
At the University of Warwick the placements werelinked to a module on contemporary British politics, while at Coventry University placements were offered on modules on British politics and the European Union respectively. At Oxford Brookes University, placements were married to the Independent Study Module. Therefore the placements were embedded on formal modules of study and were integrated into the various patterns of assessment, which we amended where necessary. They were also embedded in the sense that the placement opportunities were identified and negotiated with the providers so as to tie the placement activities as closely as possible to the specific learning outcomes of the above modules. While this was fairly time consuming in the initial stages (we wrote to over 120 potential placement providers and visited each of the eighteen placement providers who participated in the project), once established most of the partnerships prospered into further rounds of placements and the benefits in terms of student learning were clear.

\section{A research-based approach}

We attribute much of the success of such short placement experiences to our specificapproach to placement learning. To impress on placement providers and students alike that we thought of the placements primarily in terms of learning opportunities, we made a conscious decision to drop the four-letter word 'work' from all of our documentation, such as our information for students and placement providers, partnership agreements, and health and safety information. ${ }^{1}$ We made clear that this was not a matter of work experience and consequently the students were never given routine or menial activities to undertake as part of their placements. Instead, guided by a pedagogical concern to include undergraduates in the research process and to make them producers rather than mere consumers of knowledge (Blackmore and Cousin, 2003-04; Boyer Commission, 
1998; Brew, 2006; Reinvention Centre for Undergraduate Research, 2007; Zamorski, 2000), we developed a research-based approach to placements (Sherrington et al, 2008).

The students we sent on placements were engaged in research in two respects: experiencing politics in action in real-world contexts and undertaking a specific research project for their placement providers. While the exact mix between these two elements of research activity varied to some extent across the placements we organised, all students were engaged in both aspects: they were independent researchers, observing how politics is conducted in specific settings, at the same time as enhancing their research skills on a specific project. The latter element of the placements was important in a number of ways: it made the placements useful to the placement providers rather than a burden (nearly every provider we visited had one or two small projects they had been meaning to get around to, but had never had time); it made it unnecessary to train the students for specific jobs, which would have been unrealistic given the short duration of the placements; and it reassured the placement providers that the students were not there to investigate them so much as to learn about and research political activity in general.

This approach proved remarkably successful, not only in ensuring that the students only engaged in worthwhile activities focused on learning (we had only one relative failure out of 36 placemen ts), but also in terms of developing their research skills and capabilities. It also suggested important implications for employability. Despite our efforts to focus on the learning opportunities afforded by placements, in their debriefings most stude nts remarked that their placements had been excellent work experience. And we came to realise that this was so in an important sense. If we move beyond thinking of placements in terms of the development of transferable or generic skills, which most students will acquire from part-time jobs and other extra-curricular experiences anyway, we recognise that a research-based approach provides students with a short but powerful narrative that is incredibly useful for personal development planning and job applications and interviews (cf. Knight 
and Yorke, 2004, pp. 94, 137-38). To take just one example, a student we placed with a regional government office undertook a review of recently revised procedures for advising government ministers. He devised a questionnaire, interviewed the head of each department, and then compiled a PowerPoint presentation of his findings, which he made to the assembled department heads and other key figures. His experience clearly demonstrates the benefits that accrue from negotiating placements centred on a specific research task. A research-based approach to placements focuses on the development of higher-order skills and, paradoxically, can be a more effective means of enhancing employability than work experience as it is traditionally conceived. To make short placements work, we should drop the word 'work'.

\section{Blogging about it: the medium matters}

There is a consensus among practitioners of all forms of experiential learning that students must be encouraged to reflect on their activities to maximise the learning potential that the experiences afford and to make connections to the academic content of their courses. However, there is also a general dissatisfaction with the reflective journal or diary of one form or another that most placement tutors ask their students to complete. While the most able students will use such diaries to record the reflections they have already achieved, many students will use the opportunity to record a blow-by-blow account of their day-to-day activities, demonstrating that they have made little or no connection to the subject matter of their courses. Moreover, there will always be the suspicion that students do not make or update their entries as required, but hurriedly complete the diary all at once immediately before it is due for submission.

'Electronic journaling' (Mills, 2001) allows us to redress many of these problems with reflective diaries. We provided every student on placement with a blog (an online log) to record their 
experiences, progress and reflections, and we found that the medium made a significant improvement to the recorded reflections of our students. They discovered that they were writing for an audience, as their blogs were not only scrutinised by their tutors and fellow students, but were also publicly available on the world wide web (except for where the students restricted access to content to just themselves and their tutors, as we requested them to do when discussing sensitive issues or mentioning people by name). So in a very real sense, not only were our students active researchers, but they were also writing for publication by posting their reflections online at the end of each day. This freed up their writing considerably, as many of them adopted styles and wrote in a detail and length that would have been unthinkable with paper-based, private journals that students are required to submit to their tutors only at the end of their placements. The fact that students knew their tutors would be reading their blogs on a frequent basis provid ed an additional incentive to keep them up to date and prevented this becoming a painful but necessary chore that could be put off until the submission deadline. The public nature of blogging also discouraged students from overly personalising their reflections and writing about their feelings, which can be a problem with paper-based journals (Woodman, 2008).

Going electronic al so had a number of other important implications. It allowed tutors to remote monitor each placement to ensure that there were no problems or emerging issues. With placements of short duration, it is not always feasible to arrange to visit students; besides, in their debriefings most students said they were pleased that we did not visit them, as this would have undermined their sense of individual autonomy and responsibility. Therefore the blogs provided an essential 'light-touch' mechanism for checking on student progress. When problems or issues did arise, they could be identified and dealt with quickly. Blogs also provided students with the means to interact with each other, as well as those students studying the same modules but who did not go on placements. Finally, the tutors occasionally intervened, posing questions or asking students to reflect on specific events they had mentioned in more depth (cf. Cooper, 1998; Mills, 2001; Stanton, 1995). 
The shaping power of assessment

We explored a number of tools and patterns of assessing students' reflections on their placement activities, including reflective journals (the sum of their blog entries), essays, reports, and interviews. In contrast to placement schemes where the placement provider awards part of the mark (e.g., McLean, 2004, p. 3), we determined that we should be assessing not the students' performance while on placement, but what they had learned by reflecting on their experiences. Telephone debriefings with placement providers ensured that students could not fabricate experiences they did not in fact have, but this never became an issue.

We found that the essay proved to be the most effective means of assessing students' reflections, as it allowed them to compare their placement experiences against the academic literature. (Essay titles were negotiated by students with their module tutors to enable students to connect the ir placement experiences to the content of their modules.) But in addition to this, we discovered that the mode of assessment can have a powerful shaping effect on the nature and success of the placements themselves. When students embarked on a placement $w$ ith a clear essay question in mind, it focused their attention and energies. One student placed with a city council, for example, devoted much of his placement to quizzing councillors and council staff about recent reforms to the scrutiny process, as this was the subject of his essay; whereas another student at the same placement provider, who was from a different university and whose placement was assessed by a learning diary, approached her placement in a more general fashion and had a markedly different experience of the council's work. The evidence is that there is no loss in terms of students being in any way blinkered by having the clear focus provided by an essay title at the outset, but much to be 
gained in terms of an enriched and more purposeful placement experience. This was especially the case when essay questions were closely related to placement research projects.

\section{Conclusion}

Many of the students who went on placements told us that this was the best thing they had done at university (the lecturers among us were unsure whether to take this as a compliment or not!). This demonstrates the important benefits that such activities can provide for students' personal development and their experience of university. However, the results of essays, bl ogs and interviews proved conclusively that placements, if properly constructed, can make a very valuable and important contribution to the way that Politics is taught at British universities. In particular, adopting a research-based approach allows us to deploy short placements that do not exclude students with part-time jobs, part-time students, or those from so-called 'non-traditional' backgrounds, while still affording a very meaningful insight into politics in action.

\section{Bibliography}

Annette, J. (2003) 'Community and Citizenship Education' in A. Lockyer, B. Crick and J. Annette (eds), Education for Democratic Citizenship. London: Ashgate.

Annette, J. (2005) 'Character, Civic Renewal and Service Learning for Democratic Citizenship in Higher Education', British Journal of EducationalStudies, 53 (3).

Barber, B. R. and Battistoni, R. (1993) 'A Season of Service', PS: PoliticalScience and Politics, 26 (2).

Battistoni, R. M. and Hudson, W. E. (eds) (1997) Experiencing Citizenship: Concepts and Models for Service-Learning in Political Science. Washington, DC: American Association for Higher Education.

Blackmore, P. and Cousin, G. (2003-04) 'Linking Teaching and Research Through Research-Based Learning', Educational Developments, 4(4). 
Boyer Commission (1998) Reinventing Undergraduate Education: A Blueprint for America's Research Universities, available at:

http://naples.cc.sunysb.edu/pres/boyer.nsf/673918d46fbf653e852565ec0056ff3e/d955b61ffddd59 0a852565ec005717ae/\$FILE/boyer.pdf.

Brew, A. (2006) Research and Teaching: Beyond the Divide. Houndmills, Basingstoke: Palgrave Macmillan

Colby, A., Beaumont, E., Ehrlich, T., and Corngold, J. (2007) Educating for Democracy: Preparing Undergraduates for Responsible Political Engagement. San Francisco: Jossey-Bass.

Colby, A., Ehrlich, T., Beaumont, E., and Stephens, J. (2003) Educating Citizens: Preparing America's Undergraduates for Lives of Moraland Civic Responsibility. San Francisco: Jossey-Bass.

Cooper, D. D. (1998) 'Reading, Writing, and Reflection' in R. A. Rhoads and J. P. F. Howard (eds) Academic Service Learning: A Pedagogy of Action and Reflection. San Francisco: Jossey-Bass.

Eyler, J. and Giles, D. E. (1999) Where's the Learning in Service-Learning? San Francisco: Jossey-Bass.

Hepburn, M., Niemi, R. and Chapman, C. (2000) 'Service Learning in College Political Science: Queries and Commentary', PS: Politics and Political Science, 33 (3).

Knight, P. and Yorke, M. (2004) Learning and Employability in Higher Education. London: Routledge Falmer.

McLean, J. (2004) 'Parliamentary and Political Placements', C-SAPFinal Report, at: www.csap.bham.ac.uk/resources/project_reports/admin/extras/14_P_04.pdf.

Markus, G. B., Howard, J. P. F. and King, D. C. (1993) 'Integrating Community Service and Classroom Instruction Enhances Learning: Results from an Experiment', Education Evaluation and Policy Analysis, 15 (4).

Mills, S. (2001) 'Electronic Journaling: Using the Web-Based, Group Journal for Service-Learning Reflection', Michigan Journal of Community Service Learning , 8 (1).

Norton, P. (2004) 'Experience-Based Learning in Parliament (Westminster): The Pilot Project', C-SAP Final Report, at:

www.c-sap.bham.ac.uk/resources/project_reports/admin/extras/17_P_04.pdf.

Norton, P. (2008) 'Parliamentary Placements: The Benefits and Challenges' in ELiSS: Enhancing Learning in the Social Sciences, 1 (1).

Reinvention Centre for Undergraduate Research (2007) 'Two-Year Evaluation', at:

http://www2.warwick.ac.uk/fac/soc/sociology/research/cetl/about/evaluation/reinvention_evaluati on july_2007.pdf

Sherrington, P., Axford, B., Blair, A., Curtis, S., Huggins, R. and Gibson, C. (2008) 'Research-Led Placements in Politics: A New Approach?', European PoliticalScience, 7 (2).

Stanton, T. K. (1995) 'Writing About Public Service Experience: The Critical Incident Journal' in A. Watters and M. Ford, A Guide for Change: Resources for Implementing Community Service Writing . New York: McGrew-Hill. 
Woodman, D. (2008) 'Up Close and Personal: Some Issues in the Assessment of Placement Learning', paper presented at The Scholarship of Engagement for Politics: Placement Learning, Citizenship and Employability national conference, $10-11^{\text {th }}$ June, at the University of Warwick.

Zamorski, B. (2000) Research-Led Teaching and Learning in Higher Education. Norwich: UEA, Centre for Applied Research in Education.

Zivi, K. D. (1997) 'Examining Pedagogy in the Service-Learning Classroom: Reflections on Integrating Service-Learning into the Curriculum' in R. M. Battistoni and W. E. Hudson (eds), Experiencing Citizenship: Concepts and Models for Service-Learning in Political Science. Washington, DC: American Association for Higher Education.

\footnotetext{
${ }^{1}$ These documents areavailable at the project website www.politicsinaction.ac.uk.
} 